\title{
Effects of Supplemental Calcium Carbonate on the Distribution of Iron, Copper, Zinc and Manganese in Digestive Tract of Sheep
}

\author{
Hideo Yano, Hajime Matsui and Ryoji Kawashima \\ Department of Animal Science, College of Agriculture, Kyoto \\ University, Kyoto-shi 606
}

(Received November 7, 1978)

\begin{abstract}
Six sheep were divided into three groups. Each group was given a ration containing respectively $0.1,0.6$ and $1.2 \%$ calcium. The dietary calcium level was adjusted by the addition of calcium carbonate. Polyethylene glycol was utilized as a marker. After 67 days feeding, all sheep were sacrificed 2 hours after the morning feeding. Digestive contents were taken from the rumen, omasum, abomasum, upper small intestine, middle small intestine, lower small intestine, cecum and colon. Iron and copper concentrations in dry matter of digesta sampled from the upper part of small intestine decreased with the elevation of dietary calcium. In the sites of rumen, omasum and ab. omasum, the copper was also lower in sheep given the highest calcium ration than in animals fed with the lowest. The decrease in iron and copper secretion into the digestive tract might be induced by a consecutive high calcium intake. Zinc in the rumen, the abomasum and the upper small intestine tended to be decreased by the addition of calcium carbonate. Manganese in dry matter of digesta taken from the colon had a trend to increase and those in supernatant from the cecum and the colon, on the contrary, lowered with the elevation of dietary calcium. These results suggested that a high calcium intake might result in the changes of zinc and manganese metabolism in ruminants.

Jap. J. Zootech. Sci., 50 (7): 465-470, 1979
\end{abstract}

It was found in our previous experiment using sheep that retentions of iron and copper were significantly decreased by the addition of calcium carbonate to rations ${ }^{1)}$. The changes of absorption or secretion of trace minerals in the gastro-intestinal tract may occur when calcium carbonate is given. Trace mineral concentrations in the digestive tract of ruminant have been investigated by several researchers ${ }^{2-k}$. However, few information is available about the effect of dietary calcium levels on trace mineral concentrations in digesta.

This experiment was conducted to study the distribution of trace minerals in the digestive tract as dietary calcium was increased.

\section{Materials and Methods}

Six corriedale wethers, weighing about $35 \mathrm{~kg}$, were divided into three groups, two animals each. The each group was given the ration containing respectively $0.1,0.6$ Jap. J. Zootech. Sci., $50(7): 465-470$ 
and $1.2 \%$ calcium. Dietary calcium levels were obtained by the supplementation of calcium carbonate (laboratory reagent grade) to the basal ration. The dietary phosphorus level was adjusted to $0.60 \%$ by the addition of dibasic sodium phosphate $\left(\mathrm{Na}_{2} \mathrm{HPO}_{4}\right)$. All sheep were given the same ration as reported in the previous experiment $^{1}$, which contained $56 \%$ of barley, $24 \%$ of wheat bran and $20 \%$ of chopped rice straw. The mineral composition of the basal ration was the following; $0.10 \%$ of calcium, $0.53 \%$ of phosphorus, $0.22 \%$ of magnesium, $409 \mu \mathrm{g} / \mathrm{g}$ of iron, $6 \mu \mathrm{g} / \mathrm{g}$ of copper, $54 \mu \mathrm{g} / \mathrm{g}$ of zinc and $142 \mu \mathrm{g} / \mathrm{g}$ of manganese. Vitamin premix was added to furnish 3,000 and $200 \mathrm{I}$. U. per kilogram feed of vitamin $A$ and $D_{3}$, respectively.

The ration was fed twice a day at a level of $1 \%$ of body weight. Water was offered ad libitum. After 67 days of feeding, all sheep was slaughtered 2 hours after the morning feeding. Polyethylene glycol 4000 (PEG) was given at a level of $2 \%$ of concentrate ration as a marker for 7 days before sacrifice. Digestive contents were collected from the rumen, omasum, abomasum, upper small intestine, middle small intestine, lower small intestine, cecum and colon. After taking the samples, $\mathrm{pH}$ in digesta were immediately determined with $\mathrm{pH}$ test paper. Supernatant fluid in digesta was obtained after centrifugation for 1 hour at $15,000 \times \mathrm{g}$. Corrected mineral concentrations in supernatant fluid were determined by the following calculation method ${ }^{9}$.

Corrected mineral concentration in supernatant fluid ( $\mu \mathrm{g}$ nutrient/g feed ingested)

$$
=\begin{aligned}
& \text { Mineral concentration } \\
& \text { in supernate }(\mu \mathrm{g} / \mathrm{m} l)
\end{aligned} \times \frac{\text { Marker concentration in feed }(\%)}{\text { Marker concentration in supernate }(\%)}
$$

Analytical samples for feed, digesta and supernatant fluid in digesta were prepared by a dry-ashing method. After the process of ashing, mineral contents were extracted by $10 \mathrm{ml}$ of $3 \mathrm{~N}$ hydrochloric acid solution and $15 \mathrm{ml}$ of purified water on a steam bath. Iron, copper, zinc and manganese concentrations in these samples were determined with an atomic absorption spectrophotometry (Jarrell-Ash, Model AA-1). PEG concentrations in supernatant fluid were determined by the method of SMITH ${ }^{5}$. Data were treated statistically as an arranged factorial design consisting of 3 diets and 7 or 8 sampling locations. After the data were analyzed by the use of variance, significant differences among means were detected by DunCaN's multiple range test ${ }^{6}$.

\section{Results and Discussion}

As shown in table $1, \mathrm{pH}$ values of digesta were lowest in the abomasum and appeared to become higher along with the small intestine. In the sites of abomasum, the $\mathrm{pH}$ values tended to increase slightly with the elevation of dietary calcium level. WHEELER and NOLLER ${ }^{7)}$ indicated that the addition of limestone increased the fecal $\mathrm{pH}$ in dairy cattle given high energy rations.

Dry matter concentrations in the sites of colon and omasum were higher and those in the abomasum and the small intestine were comparatively lower values. The effects of dietary calcium level on dry matter concentrations were not so obvious although the average values in the abomasum became lower slightly and those in the 
Table 1. Dry matter concentrations and $\mathrm{pH}$ values in digesta sampled from various sites of digestive tract.

\begin{tabular}{|c|c|c|c|c|c|c|c|c|c|}
\hline \multirow{2}{*}{$\begin{array}{c}\text { Dietary calcium } \\
\text { levels }(\%)\end{array}$} & \multirow{2}{*}{ Rumen } & \multirow{2}{*}{ Omasum } & \multirow{2}{*}{ Abomasum } & \multicolumn{3}{|c|}{ Small intestine } & \multirow{2}{*}{ Cecum } & \multirow{2}{*}{ Colon } & \multirow{2}{*}{ S.E. } \\
\hline & & & & Upper & Middle & Lower & & & \\
\hline \multicolumn{10}{|c|}{ Dry matter concentration, $\%$} \\
\hline 0.1 & 16.2 & 23.2 & 13.0 & 12.1 & 10.0 & 9.4 & 16.5 & 35.7 & \\
\hline 0.6 & 16.8 & 22.7 & 12.2 & 12.3 & 11.7 & 11.8 & 16.5 & 32.5 & \pm 0.4 \\
\hline 1.2 & 15.5 & 21.3 & 9.3 & 11.5 & 12.3 & 13.3 & 18.6 & 40.4 & \\
\hline Mean & $16.2^{\mathrm{w}}$ & $22.4^{x}$ & $11.5^{y}$ & $12.0^{Y}$ & $11.3^{y}$ & $11.5^{y}$ & $17.2^{w}$ & $36.2^{z}$ & \\
\hline \multicolumn{10}{|l|}{ Value of $\mathrm{pH}$} \\
\hline 0.1 & 6.0 & 5.7 & 2.4 & 5.3 & 7.3 & 8.5 & 8.3 & - & \\
\hline 0.6 & 6.2 & 5.9 & 2.9 & 5.3 & 2.2 & 8.5 & 8.4 & - & \pm 0.1 \\
\hline 1.2 & 5.9 & 5.9 & 3.7 & 5.6 & 7.8 & 8.4 & 8.1 & - & \\
\hline Mean & $6.0^{\circ}$ & $5.8^{\mathrm{wr}}$ & 3. $0^{x}$ & $5.4^{\mathrm{w}}$ & 7. $4^{y}$ & 8. $5^{z}$ & $8.3^{z}$ & - & \\
\hline
\end{tabular}

$\mathrm{w}, \mathrm{x}, \mathrm{y}$ and $\mathrm{z}$ : Means in the same line with different superscript letters differ significantly $(\mathrm{P}<.05)$.

Table 2. Trace mineral concentrations in dry matter of digesta sampled from the various sites of digestive tract.

\begin{tabular}{|c|c|c|c|c|c|c|c|c|c|}
\hline \multirow{2}{*}{$\begin{array}{c}\text { Dietary calcium } \\
\text { levels }(\%)\end{array}$} & \multirow{2}{*}{ Rumen } & \multirow{2}{*}{ Omasum } & \multirow{2}{*}{ Abomasum } & \multicolumn{3}{|c|}{ Small intestine } & \multirow{2}{*}{ Cecum } & \multirow{2}{*}{ Colon } & \multirow{2}{*}{ S.E. } \\
\hline & & & & Upper & Middle & Lower & & & \\
\hline \multicolumn{10}{|l|}{ Iron, $\mathrm{mg} / \mathrm{g}$} \\
\hline 0.1 & 0.21 & 0.52 & 5.28 & 3.37 & 0.71 & 4.98 & 3.19 & 0.83 & \\
\hline 0.6 & 0.15 & 2.37 & 3.68 & 1.66 & 0.63 & 0.78 & 0.79 & 1.02 & \pm 0.3 \\
\hline 1.2 & 0.26 & 0.65 & 3,57 & 0.72 & 0.72 & 1.20 & 0.68 & 1.04 & \\
\hline Mean & 0.21 & 1.18 & 4. 18 & 1.92 & 0.69 & 2.32 & 1.55 & 0.96 & \\
\hline \multicolumn{10}{|l|}{ Copper, $\mu \mathrm{g} / \mathrm{g}^{1)}$} \\
\hline 0.1 & 7.3 & 9.0 & 26.6 & 28.7 & 3.9 & 10.4 & 6.7 & 12.2 & \\
\hline 0.6 & 5.8 & 4.5 & 29.1 & 22.3 & 12.1 & 4.7 & 8.9 & 11.3 & \pm 0.7 \\
\hline 1.2 & 3.8 & 3.6 & 8.9 & 10.5 & 6.4 & 9.6 & 14.0 & 13.3 & \\
\hline Mean & $5.6^{x}$ & $5.7^{x}$ & $21.5^{y}$ & $20.5^{y}$ & $7.5^{x z}$ & $8.2^{x z}$ & $9.9^{\times 2}$ & $12.3^{x}$ & \\
\hline \multicolumn{10}{|l|}{ Zinc, $\mu \mathrm{g} / \mathrm{g}$} \\
\hline 0.1 & 144 & 179 & 159 & 478 & 63 & 148 & 141 & 216 & \\
\hline 0.6 & 171 & 85 & 209 & 586 & 127 & 65 & 122 & 152 & \pm 13 \\
\hline 1.2 & 89 & 219 & 99 & 269 & 103 & 95 & 104 & 158 & \\
\hline Mean & $135^{\star}$ & $161^{x}$ & $156^{x}$ & $444^{y}$ & $98^{x}$ & $103^{x}$ & $122^{x}$ & $175^{x}$ & \\
\hline \multicolumn{10}{|c|}{ Manganese, $\mu \mathrm{g} / \mathrm{g}$} \\
\hline 0.1 & 132 & 238 & 423 & 272 & 125 & 165 & 272 & 409 & \\
\hline 0.6 & 78 & 136 & 168 & 244 & 222 & 341 & 163 & 422 & \pm 30 \\
\hline 1.2 & 100 & 104 & 252 & 143 & 267 & 229 & 209 & 849 & \\
\hline Mean & $103^{x}$ & $159^{x}$ & $281^{x}$ & $220^{x}$ & $205^{x}$ & $245^{x}$ & $215^{x}$ & $560^{y}$ & \\
\hline
\end{tabular}

1): There were significant differences $(P<.05)$ among means of three diet groups; $1.2 \%<$ $0.6 \%$ and $0.1 \%$. $x, y$ and $z$ : Means in the same line with different superscript letters differ significantly $(\mathrm{P}<.05)$. 
Table 3. Trace mineral concentrations in supernatant fluid of digesta sampled from the various sites of digestive tract ${ }^{11}$ ( $\mu \mathrm{g} / \mathrm{g}$ feed ingested).

\begin{tabular}{|c|c|c|c|c|c|c|c|c|c|}
\hline \multirow{2}{*}{$\begin{array}{c}\text { Dietary calcium } \\
\text { levels }(\%)\end{array}$} & \multirow{2}{*}{ Rumen } & \multirow{2}{*}{ Omasum } & \multirow{2}{*}{ Abomasum } & \multicolumn{3}{|c|}{ Small intestine } & \multirow{2}{*}{ Cecum } & \multirow{2}{*}{ Colon } & \multirow{2}{*}{ S.E. } \\
\hline & & & & Upper & Middle & Lower & & & \\
\hline \multicolumn{10}{|l|}{ Iron } \\
\hline 0.1 & 10.7 & 44.8 & 5.8 & 36.3 & 12.7 & 25.3 & 10.3 & $11: 1$ & \\
\hline 0.6 & 9.5 & 105.5 & 4.5 & 24.9 & 11.1 & 18.3 & 37.0 & 13.4 & \pm 2.0 \\
\hline 1.2 & 9.2 & 50.5 & 5.6 & 19.0 & 15.3 & 12.6 & 7.5 & 10.7 & \\
\hline Mean & $9.8^{x}$ & $66.9^{y}$ & $5.3^{x}$ & $26.7^{z}$ & $13.0^{x z}$ & 18. $7^{x z}$ & 18. $3^{x z}$ & $11.7^{x x}$ & \\
\hline \multicolumn{10}{|l|}{ Copper } \\
\hline 0.1 & 0.5 & 4.5 & 0.8 & 2.6 & 0.9 & 0.9 & 0.8 & 0.9 & \\
\hline 0.6 & 0.5 & 6.0 & 0.7 & 4.9 & 1.0 & 1.2 & 0.8 & 1.8 & \pm 0.4 \\
\hline 1.2 & 1.6 & 10.2 & 0.4 & 2.8 & 0.9 & 0.9 & 0.4 & 0.5 & \\
\hline Mean & $0.9^{x}$ & $6.9^{y}$ & $0.6^{x}$ & $3.4^{x}$ & $0.9^{x}$ & $1.0^{x}$ & $0.7^{x}$ & $1.1^{x}$ & \\
\hline \multicolumn{10}{|l|}{ Zinc } \\
\hline 0.1 & 9.4 & 16.3 & 7.5 & 115.3 & 9.8 & 9.1 & 7.8 & 8.1 & \\
\hline 0.6 & 3.1 & 55.6 & 14.4 & 70.9 & 2.0 & 15.4 & 16.1 & 9.6 & \pm 3.0 \\
\hline 1.2 & 5.4 & 18.0 & 23.9 & 100.7 & 15.5 & 7.1 & 6.6 & 14.3 & \\
\hline Mean & $6.0^{*}$ & $30.0^{x}$ & $15.3^{x}$ & $95.6^{y}$ & $10.8^{x}$ & $10.5^{x}$ & $10.2^{x}$ & $10.7^{x}$ & \\
\hline \multicolumn{10}{|l|}{ Manganese } \\
\hline 0.1 & 9.6 & 8.0 & 8.0 & 14.2 & 2.7 & 3.5 & 4.5 & 5.8 & \\
\hline 0.6 & 7.0 & 11.7 & 8.3 & 12.6 & 1.6 & 1.5 & 2.7 & 2.4 & \pm 0.5 \\
\hline 1.2 & 8.8 & 11.8 & 10.7 & 8.8 & 1.3 & 1.2 & 0.9 & 1.0 & \\
\hline Mean & $8.5^{x}$ & $10.5^{x}$ & $9.0^{x}$ & $11.9^{x}$ & $1.9^{y}$ & 2. $1^{y}$ & 2. $7^{y}$ & 3. $1^{y}$ & \\
\hline
\end{tabular}

1): Mineral concentrations in supernatant fluid were corrected with the marker. $x, y$ and $z$ : Means in the same line with different superscript letters differ significantly $(\mathbf{P}<.05)$.

lower small intestine became higher with the elevation of dietary calcium level.

Iron and copper concentrations in supernatant fluid were likely to increase in the omasum (Table 3). The digesta sampled from the omasum had a very low water con. tent in comparison with those from the rumen, abomasum and small intestine. OмоRI ${ }^{8}$ and Perry et al. ${ }^{9)}$ indicated that digesta taken from the omasum of calves contained low water. It seems probable that iron and copper are drived out of solid phase of digesta.

Iron concentrations in digesta and supernatant fluid collected from the upper part of small intestine tended to decrease with the elevation of dietary calcium (Table 2 and 3). It is well established that iron is secreted via bile into the digestive tract ${ }^{10}$. 11). Therefore, it seems that net secretion of iron is decreased by the elevation of dietary calcium.

As increasing the dietary calcium, copper concentrations in dry matter of digesta taken from the rumen, omasum, abomasum and upper small intestine appeared to lower (Table 2). It was reported in rats that copper was largely absorbed from the stomach $^{12}$. Recently, IVAN and GRIEVE ${ }^{4}$ indicated that net absorption of copper took place in the stomach region of calves. Although it was not known clearly whether the 
decreasing of copper concentrations in these regions resulted from the increase of absorption or the decrease of secretion, the elevation of dietary calcium appeared to reduce copper concentrations in these sites of the digestive tract.

In the trial of mineral balance ${ }^{1)}$, negative retentions of iron and copper were observed in sheep given the highest calcium ration. From the data of the present experiment, causes as to why negative retentions of these minerals were induced were not clarified. However, it is conceivable that the elevation of dietary calcium results in the decrease in body stores of iron and copper, which is followed by the reduction of secretion of these minerals into the digestive tract of sheep.

MILLER and CRAGLE ${ }^{19)}$ demonstrated that zinc was absorbed from the abomasum and the lower small intestine, and secreted into the upper part of small intestine of calves. The results that zinc concentrations of supernatant fluids elevated in the upper small intestine and lowered in the middle and lower small intestine (Table 3) supported the observations by them. However, no obvious trend was found for the zinc concentration of supernatant fluid in the abomasum.

In the sites of rumen, abomasum and upper and lower small intestine, the zinc concentrations in digesta from sheep given the highest calcium ration tended to be lower than those from animals given the other rations (Table 2). These changes of zinc were similar to the cases of iron and copper of which requirements were enhanced by the elevation of dietary calcium ${ }^{14.15}$. Although a high dietary calcium level reduces zinc absorption in monogastric animals ${ }^{16)}$, the effects of dietary calcium on zinc requirement are not established in ruminants.

Miller et al. ${ }^{17)}$ reported that the digesta from the cecum and colon had high manganese concentrations in calves. IVAN and GRIEVE') also found a considerable net secretion of manganese into the cecum of calves. The supernatant manganese concentrations corrected with the marker appeared to elevate to a little extent in the cecum and colon when the lower calcium rations were given to sheep (Table 3).

The manganese in digesta taken from the colon had a trend to increase and those in supernatant from the cecum and colon, on the contrary, lowered with the elevation of dietary calcium level (Table 2 and 3). Schatble and Bandemer ${ }^{18)}$ showed that the increasing of calcium phosphate concentrations removed ionic manganese from solution through adsorption by the insoluble portion of the compound. $\mathrm{VAGG}^{19)}$ demonstrated using a radioisotope technique that the endogenous loss of manganese was increased by the elevation of dietary calcium in dairy cows.

On the other hand, OGURA ${ }^{20)}$ concluded that feeding with an excessive amount of calcium had no inhibitory effect upon the absorption of manganese in chicks. In the previous balance trial ${ }^{1}$, the retention of zinc and manganese were insignificantly affected by the addition of calcium carbonate. Further study, therefore, will be required to determine the effect of calcium carbonate on the metabolism of zinc and manganese in cattle and sheep. 


\title{
References
}

1) Yano, H., M. Nokata and R. Kawashima, Jap. J. Zootech. Sci., 49: 625-631. 1978.

2) Breminer, I., Br. J. Nutr., 24: 769-783. 1970.

3) Grace, N. D., Br. J. Nutr., 34: 73-82. 1975.

4) Ivan, M. and C. M. Grieve, J. Dairy Sci., 59: 1764-1768. 1976.

5) Sмiтн, R. H., J. Agric. Sci., 52: 72-78. 1959.

6) Duncan, D. B., Biometrics, 11: 1-42. 1955.

7) Wheeler, W. H. and C. H. Noller, J. Dairy Sci., 59: 1788-1793. 1976.

8) OмоRI, S., Bull. Nat. Inst. Anim. Ind., 24: 51-58, 1971.

9) Perry, S. C., R. G. Cragle and J. K. Miller, J. Nutr., 93: 283-290. 1967.

10) Thomas, J.W., J. Dairy Sci., 53: 1107-1123. 1970.

11) Underwood, E. J., Trace Elements in Human and Animal Nutrition. 3rd ed. 77-78. Academic Press. New York and London. 1971.

12) Van Campen, D. R. and E. A. Mitchell, J. Nutr., 86: 120-124. 1965.

13) Miller, J. K. and R. G. Cargle, J. Dairy Sci., 48: 370-373. 1965.

14) Kirchgessner, M., World Rev. Anim. Prod., 4: 41-50. 1965.

15) O’Dell, B. L., Annals N.Y. Acad. Sci., 199: 70-81. 1972.

16) Miller, W. J., J. Dairy Sci., 53: 1123-1135. 1970.

17) Miller, W. J., M.W. Neathery, R. P. Gentry, D. M. Blackmon, J. W. Lassiter and F. M. Pate, J. Anim. Sci., 34: 460-464. 1972.

18) Schaible, P. J. and S. L. Bandemer, Poultry Sci., 21: 8-14. 1942.

19) VAGG. M. J., Mineral Studies with Isotopes in Domestic Animals. 121-124. International Atomic Energy Agency. Vienna. 1971.

20) Ogura, Y., Nat. Inst. Anim. Hlth Quart., 17: 163-170. 1977.

\section{飼料中への炭酸カルシウム添加がめん羊の消化管内容物中 鉄, 銅, 亜鉛, マンガン濃度に及ぼす影響}

\author{
矢野秀雄・松井基・川島良治 \\ 京都大学農学部畜産学科, 京都市 606
}

\begin{abstract}
6 頭の去勢めん羊を 2 頭ずつ 3 区に分けて，飼料中カ ルシウム含量が $0.1 ， 0.6,1.2 \%$ あるる飼料をそれでれ 各区のめん羊に給与した，飼料中のカルシウム水準は宸 酸カルシウんの添加により調整し，ポリエチレンダリコ 一ルをマーカーとして用いそ. 67 日間飼着した後，朝の 給餌後 2 時間目にと殺した，消化管内容物は第 1 胃，第 3 胃，第 4 胃，小腸上部，小腸中部，小腸下部，盲腸， 結星から採取した．小腸上部では消化管内容物乾物中の 鉄㧍よび銅濃度は飼料中カルシウム濃度の增加により低 下した，高カルシウム飼料を与えると第 1 胃，第 3 胃,
\end{abstract} 第 4 胃での消化管内容物中銅濃度は低くなる傾向にあっ

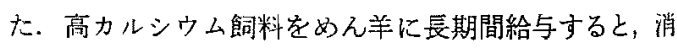
化管内への鉄，銅の再排泄は低下寸るものと考元られ た. 飼料中への炭酸カルシウム添加により，消化管内容 物中亜鉛浱度は，第 1 胃，第 4 胃，小腸上部で低下主る 傾向にあった．結腸での消化管内容物マンガン浱度は， 飼料中カルシウム濃度の増加にともない堌加する傾向に あり，逆に盲腸，結腸内容物の上澄み液中マンガン浱度 は低下した：これらの結果から高かルシウム飼料を反す う動物に給与すると, 亜鉛, マンガン代謝にも変化を及 ぼすように思われた。

日畜会報, $50(7) ： 465-470,1979$ 